\title{
Soil and leaf fertilization of lettuce crop with cow urine
}

\author{
Nelson Licínio C de Oliveira ${ }^{1 *}$; Mário Puiatti2 ${ }^{2 * *}$; Ricardo Henrique S Santos ${ }^{2 * *}$; Paulo R Cecon ${ }^{3 * *}$; Pe- \\ dro Henrique R Rodrigues $2 * * *$

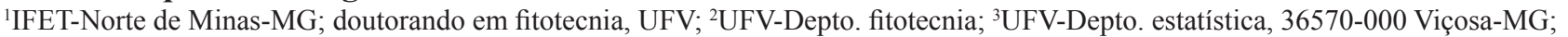 \\ *Bolsista CAPES-PIQDTec-MEC; **Bolsista pesquisador CNPq; ***Bolsista IC-FAPEMIG; nelsonlco@yahoo.com.br, mpuiatti@ufv.br
}

\begin{abstract}
The use of cow urine can be considered an agricultural practice of low cost for farmers. Nevertheless, its efficiency on crop needs research information. The present research aimed to evaluate the effect of cow urine on the growth and yield of 'Regina 2000' lettuce, in an experiment carried out from January 13, 2006 to March 22, 2006. The experiment was set up with 12 treatments, in a split-plot design and four completely randomized blocks. The soil and leaf applications were installed in the plot. In the split-plot, cow urine was applied at different concentrations $(0.00 ; 0.25 ; 0.50 ; 0.75 ; 1.00$ and $1.25 \%)$. The plot presented four rows with $1.75 \mathrm{~m}$ each, in $0.25 \times 0.25 \mathrm{~m}$ spacing. The six central plants of the two central rows formed the sampled split-plot. At harvest, the following variables were evaluated: fresh (FLM) and dry (DLM) leaf mass, fresh (FSM) and dry (DSM) stem mass, stem length (SL), fresh (FRM) and dry (DRM) root mass, fresh (FHM) and dry (DHM) head mass and commercial yield (CY). The increase in cow urine concentrations increased the performance of all lettuce characteristics, except DRM, which presented reduction, and DSM and FRM, which were not affected. The highest yield was obtained with the concentration of $1.25 \%(17.00 \mathrm{t}$ ha-1) applied to leaves and with $1.01 \%$ (14.92 tha-1), applied to soil, corresponding, respectively to increases of $28.1 \%$ and $47.3 \%$, in comparison to the control. Application to leaves, in comparison to application to soil, resulted in greater FLM $(0.50$ and $1.25 \%)$, SL $(0.50 ; 0.75$ and $1.25 \%)$, FSM and FRM (0.5\%), FHM and CY (0.50 and $1.25 \%)$, but lower DSM and FRM (1.25\%) and DRM (1.0 and 1.25\%). The application of cow urine solution at $1.25 \%$ to leaves or $1.0 \%$ to soil is recommended for lettuce crops.
\end{abstract}

Keywords: Lactuca sativa, plant growth, biofertilizer.

\section{RESUMO}

Fertilização com urina de vaca em alface via solo e foliar

A utilização da urina de vaca pode ser considerada uma prática de custo baixo para os produtores rurais. Todavia, a sua eficiência sobre as culturas carece de informações da pesquisa. Assim, objetivou-se avaliar o efeito da urina de vaca sobre o crescimento e produção da alface em experimento conduzido de 13 de janeiro de 2006 a 22 de março de 2006, com a cv. Regina 2000. O experimento foi constituído de 12 tratamentos, em esquema de parcelas subdivididas, delineamento de blocos ao acaso, com quatro repetições. Nas parcelas foram alocadas as aplicações das soluções de urina (solo e foliar) e, nas subparcelas, as concentrações $(0,00 ; 0,25 ; 0,50 ; 0,75 ; 1,00$ e $1,25 \%$ ). A subparcela foi constituída por quatro fileiras de $1,75 \mathrm{~m}$, espaçamento de $0,25 \times 0,25$ m e consideraram-se, como úteis, as seis plantas centrais das duas fileiras centrais. Na colheita foram avaliados a massa da matéria fresca (MFF) e seca de folhas (MSF); massa da matéria fresca (MFC) e seca de caule (MSC); comprimento de caule (CC); massa da matéria fresca (MFR) e seca de raízes (MSR); massa da matéria fresca (MFCA) e seca da cabeça (MSCA) e produtividade comercial (PROD). Exceto a MSR, que diminuiu e MSC e MFR que não foram alteradas na aplicação via foliar, as demais características avaliadas apresentaram incremento às concentrações aplicadas. Maior produtividade de cabeça foi obtida com concentrações de $1,25 \%$ $\left(17,0 \mathrm{t} \mathrm{ha}^{-1}\right)$ aplicada via foliar e de $1,01 \%\left(14,9 \mathrm{t} \mathrm{ha}^{-1}\right)$ aplicada via solo correspondendo, respectivamente, a aumentos em produtividade de $28,1 \%$ e de $47,3 \%$, comparados à testemunha. A aplicação foliar, comparada via solo, proporcionou maior MFF (0,50 e 1,25\%), CC $(0,50 ; 0,75$ e $1,25 \%)$, MFC e MFR $(0,5 \%)$, MFCA e PROD $(0,50$ e $1,25 \%)$ e menores MSC e MFR (1,25\%) e MSR (1,0 e 1,25\%). Sugere-se, no cultivo da alface, a aplicação das doses de solução de urina às concentrações de $1,25 \%$ via foliar ou de $1,0 \%$, via solos.

Palavras-chave: Lactuca sativa, crescimento de plantas, biofertilizante.

(Recebido para publicação em 11 de junho de 2008; aceito em 30 de julho de 2009) (Received in June 11, 2008; accepted in July 30, 2009)

L ettuce is the most cultivated and consumed foliage vegetable in the world. Manure and organic compounds are commonly used in lettuce crops because they improve productivity and quality of this crop (Zárate et al., 1997; Villas Boas et al., 2004; Lopes et al., 2005).

Composting is a common practice that involves the cycling of plant and animal residues, mainly in the organic cultivation system, with positive results for crops and soil, which have already been proved by researches. On the other hand, cow urine is also an organic product which lacks scientific research, although it has already been tested and presented relatively good results for several crops since the last decade, mainly by farmers in Rio de Janeiro
State (Gadelha et al., 2002; 2003; PESAGRO-RIO, 2002).

Cow urine is believed to provide nutrients to plants at low cost (PESAGRO-RIO, 2002). Also, this resource is available in small farms and allows the integration between cattle raising and vegetable crop activities, decreasing the cost of production due to the lower expenditure with fertilizers. 
Therefore, cow urine is considered an alternative for plant nutrition, metabolic activation and pest and disease control (Boemeke, 2002; PESAGRO-RIO, 2002; Achliya et al., 2004). Such inferences, however, lack scientific evidence.

Positive results in growth and production have been reported for cow urine application in pineapple, okra, gilo, eggplant, tomato, pepper, cucumber and green-bean crops. In pineapples, monthly pulverizations of $40 \mathrm{~cm} 3$ of solution at $2.5 \%$ have been used, in the center of the rosette, starting from the second planting month. For okra, gilo and eggplant, the biweekly application of a solution at $1.0 \%$ has been recommended for leaf pulverizations. For tomato, pepper, cucumber, green-beans and kale, positive effects of weekly pulverizations at $0.5 \%$ were observed (PESAGRO-RIO, 2002; Gadelha et al., 2002; 2003).

The application to soil of $20 \mathrm{ml}$ per plant of a cow urine solution at the concentration of $0.86 \%$ provided $10 \%$ of increase in fresh matter of lettuce cv. Romana, in comparison to the control (Gadelha et al., 2003), which demonstrates the potential for its use in this crop. Nevertheless, the understanding of the effects of cow urine on plant growth still demands further studies. The present work aimed at evaluating the effects of cow urine, applied to plant leaves and soil, on the growth and yield of lettuce under organic cultivation.

\section{MATERIAL AND METHODS}

The experiment was conducted in the field of the Universidade Federal de Viçosa, $\left(20^{\circ} 45^{\prime} \mathrm{LS}, 42^{\circ} 51^{\prime}\right.$ LW and $651 \mathrm{~m}$ of altitude), from $01 / 13 / 2006$ to $03 / 22 / 2006$. The crop was carried out using organic practices, such as the substrate solarization for sapling production, fertilization only with cow manure, insect pest control with Nim oil and manual control of spontaneous plants. To avoid rain interferences on the forms of application of cow urine (soil and leaves) and the concentrations applied, the cultivation was performed in a chapel type greenhouse, with
$10.4 \times 16.0 \mathrm{~m}$, headroom of $2.0 \mathrm{~m}$ and central span height of $3.30 \mathrm{~m}$, with a low-density $(150 \mu \mathrm{m})$ additivated polyethylene film cover, and open frontal and lateral areas.

During the cultivation cycle, the averages of the minimum $\left(17.5^{\circ} \mathrm{C}\right)$ and maximum $\left(41.6^{\circ} \mathrm{C}\right)$ air temperatures at the plant canopy level; the minimum $\left(22.5^{\circ} \mathrm{C}\right)$ and maximum $\left(36.8^{\circ} \mathrm{C}\right)$ temperatures of the soil at $15 \mathrm{~cm}$ depth and the air relative humidity $(30.0 \%)$ (minimum) and (97.0\%) (maximum) were recorded in a thermohygrometer (HT-208 model).

The cultivation was carried out in beds, with lateral areas of masonry, with the dimensions of $10.0 \times 1.0 \times 0.30 \mathrm{~m}$ (length, width and height), westbound. The beds were filled with soil removed from the superficial layer $(0-10 \mathrm{~cm})$ of a forest soil classified as Cambic Ustalfs, presenting a clayey-sandy texture and the following chemical characteristics: $\mathrm{pH}$ in water $(1: 2.5)=5.2 ; \mathrm{P}=320.0 \mathrm{mg}$ $\mathrm{dm}^{-3}$; P-rem $=27.1 \mathrm{mg} \mathrm{L}^{-1} ; \mathrm{K}=48.0 \mathrm{mg}$ $\mathrm{dm}^{-3} ; \mathrm{Na}=12.0 \mathrm{mg} \mathrm{dm}^{-3} ; \mathrm{S}=64.4 \mathrm{mg}$ $\mathrm{dm}^{-3} ; \mathrm{Ca}^{2+}=4.9$ cmolc dm ${ }^{-3} ; \mathrm{Mg}^{2+}=0.5$ cmolc dm ${ }^{-3} ; \mathrm{Al}^{3+}=0.4$ cmolc dm $^{-3} ; \mathrm{H}^{+}$ $\mathrm{Al}=11.1 \mathrm{cmolc} \mathrm{dm}^{-3} ; \mathrm{SB}=5.6 \mathrm{cmolc}$ $\mathrm{dm}^{-3}$; CTC (t) $=6.0$ cmolc dm dm $^{-3}$ CTC $(\mathrm{T})=16.6 \mathrm{cmolc} \mathrm{dm}^{-3} ; \mathrm{V}=33.0 \% ; \mathrm{m}$ $=7.0 \%$ and $\mathrm{Na}=0.9 \%$; $\mathrm{MO}=4.8 \mathrm{dag}$ $\mathrm{kg}^{-1} ; \mathrm{Zn}=20.3 \mathrm{mg} \mathrm{dm}^{-3} ; \mathrm{Fe}=157.2 \mathrm{mg}$ $\mathrm{dm}^{-3} ; \mathrm{Mn}=40.8 \mathrm{mg} \mathrm{dm}^{-3} ; \mathrm{Cu}=0.8 \mathrm{mg}$ $\mathrm{dm}^{-3}$ and $\mathrm{B}=2.3 \mathrm{mg} \mathrm{dm}^{-3}$.

The soil correction was based on the method of neutralization of $\mathrm{Al}^{3+}$ and elevation in the contents of $\mathrm{Ca} 2+$ and $\mathrm{Mg}^{2+}$ (Alvarez \& Ribeiro, 1999) and recommendations of fertilizers for the crop (Fontes, 1999). The amount of 0.75 tha-1 of surface liming was used, PRNT $100 \%$, incorporated to the soil 30 days before the transplant of the saplings, followed by daily irrigations. Five days before the transplant, the planting fertilization was carried out, using only tanned cattle at a quantity equivalent to $31.6 \mathrm{t} \mathrm{ha}^{-1}$, in dry matter basis; the manure presented the following characteristics: $\mathrm{pH}$ in water $(1: 2.5)=$ $8.5 ; \mathrm{N}=2.4 \% ; \mathrm{P}=0.8 \% ; \mathrm{K}=0.9 \% ; \mathrm{Ca}^{2+}$ $=1.9 \% ; \mathrm{Mg}^{2+}=0.7 \% ; \mathrm{S}=0.5 \% ; \mathrm{C} . \mathrm{O}=$ $15.3 \% ; \mathrm{C} / \mathrm{N}=6.4 ; \mathrm{Zn}=370.0 \mathrm{mg} \mathrm{dm}^{-3}$; $\mathrm{Fe}=128,916.0 \mathrm{mg} \mathrm{dm}^{-3} ; \mathrm{Mn}=1,827.0$ $\mathrm{mg} \mathrm{dm}{ }^{-3} ; \mathrm{Cu}=66.0 \mathrm{mg} \mathrm{dm}^{-3} ; \mathrm{B}=41.0$ $\mathrm{mg} \mathrm{dm}{ }^{-3} ; \mathrm{Cd}=0.0 \mathrm{mg} \mathrm{dm}^{-3} ; \mathrm{Pb}=56.0$ $\mathrm{mg} \mathrm{dm}^{-3} ; \mathrm{Ni}=1.0 \mathrm{mg} \mathrm{dm}^{-3}$ and $\mathrm{Cr}=0.0$ $\mathrm{mg} \mathrm{dm}^{-3}$ and humidity $=43.1 \%$. For the first year, the following percentages of conversion of the nutrients applied were considered, through cattle manure, for the mineral form: $\mathrm{N}=50 \%, \mathrm{P} 2 \mathrm{O} 5=60 \%$ and $\mathrm{K} 2 \mathrm{O}=100 \%$ (CFSEMG, 1999).

The experiment comprised 12 treatments corresponding to six concentrations of cow urine and two forms of application (soil and leaf). It was conducted in subdivided plots, in a randomized block design, with four replications. The forms of cow urine application (soil and leaf) were allocated in the plots, while the concentrations of the solution of the cow urine $(0.00$; $0.25 ; 0.50 ; 0.75 ; 1.00$ and $1.25 \%$ ) were allocated in the subplots. The experimental unit was formed by four rows of $1.75 \mathrm{~m}$ of length, with plants in the spacing of $0.25 \times 0.25 \mathrm{~m}$. The six central plants of the two central rows were considered as the useful area.

The urine was collected on a single day from 15 lactating dairy cows of the UFV-Departamento de Zootecnia, from a stock of good health herd. The urine was stored in a disinfected plastic carboy, which remained closed, in an aired shelter. It started to be applied on the fourth day of storage, when one sample was removed and sent to the agronomical laboratory UNITHAL, in Campinas, São Paulo State, for analyses, presenting the following composition (in $\mathrm{mg} \mathrm{L}^{-1}$ ): $\mathrm{N}=12,600.0 ; \mathrm{P}=97.8 ; \mathrm{K}=$ 2,666.0; $\mathrm{Ca}=5.0 ; \mathrm{Mg}=330.0 ; \mathrm{S}=45.0$; $\mathrm{Fe}=4,0 ; \mathrm{Mn}=4.0 ; \mathrm{Cu}=2.0 ; \mathrm{Zn}=8.0$; $\mathrm{B}=110.0 ; \mathrm{Na}=2,000.0 ; \mathrm{Co}=6.0 ; \mathrm{Mo}$ $=9.0 ; \mathrm{Al}=2,900.0 ; \mathrm{Cl}=1,700.0$ and density $=1.0 \mathrm{~g} \mathrm{~mL}^{-1}$.

The concentrations of the solutions were achieved by the dilution of the urine in distilled water. A total volume of $60 \mathrm{ml}$ of urine solution per plant of lettuce was applied to each application form and for each concentration. This total volume $(60 \mathrm{ml})$ was divided into five weekly applications, starting one week after the transplantation of the saplings, by applying, respectively, 5; 5; $10 ; 20$ and $20 \mathrm{ml}$ of the solution per plant at a time. In the dose of $0.0 \%$, only water was applied. These applied solution volumes were defined according to the 
development of the plant leaf area.

Considering the volume of $60 \mathrm{ml}$ of urine solution applied per plant, and a population of 128,000 plants ha- 1 , the amounts of the nutrients applied per hectare, for the highest concentration of cow urine, of $1.25 \%$ were (in $\mathrm{g} \mathrm{ha}^{-1}$ ): $\mathrm{N}$ $=1,200.00 ; \mathrm{P}=9.47 ; \mathrm{K}=255.87 ; \mathrm{Ca}=$ $0.48 ; \mathrm{Mg}=31.68 ; \mathrm{S}=4.32 ; \mathrm{Fe}=0.38$; $\mathrm{Mn}=0.38 ; \mathrm{B}=10.56 ; \mathrm{Cu}=0.19 ; \mathrm{Zn}=$ $0.77 ; \mathrm{Na}=192.00 ; \mathrm{Cl}=163.20 ; \mathrm{Co}=$ $0.58 ; \mathrm{Mo}=0.86 ; \mathrm{Al}=278.40$.

The seedlings of cultivar 'Regina2000 ' were obtained by sowing on a 200 cells expanded polystyrene tray on $01 / 13 / 2006$ in a protected environment. The trays were filled with substrate solarized for seven days. The substrate was composed of a mixture of earth to fill the cultivation beds and matured cow manure in the $1: 1(\mathrm{v}: \mathrm{v})$ proportion. The transplant was performed when the seedlings presented four definitive leaves, 25 days after sowing. Drip irrigation was performed daily, with the application of a water volume defined according to tensiometers installed in the plots at $15 \mathrm{~cm}$ depth.

The harvest occurred 46 days after the transplant, when the plants presented the maximum development without bolting incidence. The following characteristics were evaluated in three plants randomly chosen in the useful area: fresh matter mass (FLM) and dry matter mass (DLM) of the leaves; fresh matter mass (FSM) and dry matter mass (DSM) of the stem; fresh matter mass (FRM) and dry matter mass (DRM) of the root; length of the stem (SL); fresh matter mass of the head (FHM); dry matter mass of the head (DHM) and commercial productivity (CY). After the cutting of the aboveground part (head), the soil started to be carefully removed from the root system, which was weighed, after being washed and dried. The dry mass was obtained after drying in an oven, with forced ventilation at $65^{\circ} \mathrm{C}$, up to constant mass. The yield (CY) was achieved by multiplying the average fresh matter of the head by the population of the plants present in an area of $8,000 \mathrm{~m}^{2}$ (useful area), expressed in $\mathrm{t}$ ha-1. The data were submitted to the analysis of variance. Regardless of the significance of the interaction, their deployment was performed for all the characteristics because of the interest of the study. The averages of the qualitative factor (forms of application) were compared by the Tukey test $(\mathrm{p}<0.05)$. The analysis of regression was carried out for the quantitative factor (urine concentrations). The models were chosen according to the significance of the regression coefficients, using the $\mathrm{t}$ test $(\mathrm{p}<0.05)$, and the determination coefficient $\left(\mathrm{R}^{2}\right)$.

\section{RESULTS AND DISCUSSION}

Most of the evaluated characteristics presented an increase with the increase of the concentrations of the applied solutions, either on soil or on leaves. However, the leaf application of urine did not affect the DSM and FRM and reduced the DRM (Figure 1). The FLM presented an increasing linear response to the leaf application and a quadratic response to the soil application (Figure 1A), while the DLM presented a linear increment for both types of applications (Figure 1B). Under the leaf application, the FLM raised from 94.7 to $119.8 \mathrm{~g} /$ plant in the concentration of $1.25 \%$, corresponding to the increment of $26.5 \%$ of mass per plant. In the soil application, the highest FLM value (105.89 g/plant) was achieved with the concentration of $0.99 \%$ (Figure 1A). In the concentrations 0.50 and $1.25 \%$, the plants that received the leaf applications of urine presented a higher FLM (Table 1).

The DLM presented an increment of 1.28 and $1.44 \mathrm{~g} /$ plant, in the leaf and soil applications, respectively, in the concentration of $1.25 \%$ (Figure 1B), without any significant difference between the types of application (Table 1).

The higher response in FLM to the leaf application may have occurred due to the efficiency of the fertilizer absorption by the leaves (Faquin, 1994). The elements $\mathrm{K}, \mathrm{N}$ and $\mathrm{Cl}$, in the form of ion $\mathrm{K}+$, NO3- and $\mathrm{Cl}$-, even in small quantities due to the low applied concentrations, may have caused a cell increase, because of the osmotic effect (Faquin, 1994), promoting plant growth.
Other research reveal that increments in the production of fresh and dry matter mass in lettuce plants occur using nitrogen fertilization, either in the mineral or organic form (Santos et al., 2001; Prado et al., 2002; Lopes et al., 2005; Pôrto, 2006).

Nevertheless, in those works, the provided quantities of nutrients were much higher than those provided by the urine solutions used in the present work. This demonstrates that other factors, besides the quantities of applied nutrients, stimulate the growth of lettuce plants. The hormonal effect, possibly exerted by the presence of auxin (AIA) in cow urine (Gadelha, 2003), would be associated to this kind of response.

Santos et al. (2001) verified that the application of increasing doses of organic compounds provided a lower production of dry matter in lettuce plants. However, Primavesi (1985) and Vidigal et al. (1997) associated the increase of dry matter content of leaves to $\mathrm{N}$ deficiency. In the present work, both dry and fresh mass increased with the increase of urine concentrations, indicating their stimulating effect on plant growth.

The stem length (SL) presented a response of the square root type to the urine concentrations applied on the leaves, achieving $6.97 \mathrm{~cm} /$ plant in the concentration of $1.25 \%$. When applied to the soil, the response was linear, ascending with the increment of 0.83 $\mathrm{cm} /$ plant, going from zero to $1.25 \%$ (Figure 1C). In the concentrations of $0.50 ; 0.75$ and $1.25 \%$, the application of solutions on the leaves, in comparison to the application on the soil, provided a higher SL (Table 1). The stem fresh matter (FSM) presented a linear increasing response to the applied urine concentrations, both on leaves and soil, corresponding, respectively, to an increase of 3.81 and $3.75 \mathrm{~g} /$ plant, when it went from 0.0 to $1.25 \%$, (Figure 1D).

Only in the concentration of $0.50 \%$, the plants which received solution on their leaves presented a FSM higher than those which received soil application (Table 1). On the other hand, the stem dry matter (DSM) did not change with the leaf application, presenting 
Table 1. Average values of fresh leaf matter (FLM), dry leaf matter (DLM), stem length (SL), fresh stem matter (FSM), dry stem matter (DSM), fresh root matter (FRM), dry root matter (DRM), dry head matter (DHM), fresh head matter (FHM) and commercial yield (CY) of lettuce according to the application of the concentrations of cow urine applied to soil and leaves [valores médios de massa de matéria fresca de folha (FLM), massa de matéria seca de folha (DLM), comprimento de caule (SL), massa de matéria fresca de caule (FSM), massa de matéria seca de caule (DSM), massa de matéria fresca de raiz (FRM), massa de matéria seca de raiz (DRM), massa de matéria seca de cabeça (DHM), massa de matéria fresca de cabeça (FHM) e produtividade comercial (CY) da alface em função da aplicação de concentrações de urina de vaca vias solo e folhas]. Viçosa, UFV, 2006.

\begin{tabular}{|c|c|c|c|c|c|c|c|c|c|}
\hline \multirow{2}{*}{ Characteristics } & \multirow{2}{*}{$\begin{array}{c}\text { Forms of } \\
\text { application }\end{array}$} & \multicolumn{6}{|c|}{ Concentration of cow urine $(\%)$} & \multirow{2}{*}{ CV $(\%)^{1}$} & \multirow{2}{*}{$\mathrm{CV}(\%)$} \\
\hline & & 0.00 & 0.25 & 0.50 & 0.75 & 1.00 & 1.25 & & \\
\hline \multirow{2}{*}{ FLM (g/plant) } & Soil & $73.34 \mathrm{~b}$ & $87.69 \mathrm{a}$ & $91.68 \mathrm{~b}$ & $105.57 \mathrm{a}$ & $111.33 \mathrm{a}$ & $100.52 \mathrm{~b}$ & \multirow{2}{*}{14.76} & \multirow{2}{*}{8.42} \\
\hline & Leaves & $90.83 \mathrm{a}$ & 98.83 a & $109.43 \mathrm{a}$ & $117.65 \mathrm{a}$ & $107.55 \mathrm{a}$ & $119.52 \mathrm{a}$ & & \\
\hline \multirow{2}{*}{ DLM (g/plant) } & Soil & $3.85 \mathrm{~b}$ & $4.69 \mathrm{a}$ & $5.08 \mathrm{a}$ & $4.95 \mathrm{a}$ & $5.18 \mathrm{a}$ & $5.60 \mathrm{a}$ & \multirow{2}{*}{6.31} & \multirow{2}{*}{7.82} \\
\hline & Leaves & $4.56 \mathrm{a}$ & $4.36 \mathrm{a}$ & $5.20 \mathrm{a}$ & $5.37 \mathrm{a}$ & $5.11 \mathrm{a}$ & $5.87 \mathrm{a}$ & & \\
\hline \multirow{2}{*}{$\mathrm{SL}(\mathrm{cm})$} & Soil & $5.28 \mathrm{~b}$ & $5.60 \mathrm{a}$ & $5.43 \mathrm{~b}$ & $5.69 \mathrm{~b}$ & $6.19 \mathrm{a}$ & $6.04 \mathrm{~b}$ & \multirow{2}{*}{8.29} & \multirow{2}{*}{5.54} \\
\hline & Leaves & $6.39 \mathrm{a}$ & $5.24 \mathrm{a}$ & $6.14 \mathrm{a}$ & $6.28 \mathrm{a}$ & $6.60 \mathrm{a}$ & $6.80 \mathrm{a}$ & & \\
\hline \multirow{2}{*}{ FSM (g/plant) } & Soil & $6.60 \mathrm{~b}$ & $9.35 \mathrm{a}$ & $8.60 \mathrm{~b}$ & $10.62 \mathrm{a}$ & $10.42 \mathrm{a}$ & $10.81 \mathrm{a}$ & \multirow{2}{*}{10.48} & \multirow{2}{*}{12.92} \\
\hline & Leaves & $9.13 \mathrm{a}$ & $7.80 \mathrm{a}$ & $12.78 \mathrm{a}$ & $11.60 \mathrm{a}$ & $11.83 \mathrm{a}$ & $12.40 \mathrm{a}$ & & \\
\hline \multirow{2}{*}{ DSM (g/plant) } & Soil & $0.84 \mathrm{a}$ & $1.04 \mathrm{a}$ & $0.94 \mathrm{a}$ & $1.01 \mathrm{a}$ & $1.11 \mathrm{a}$ & $1.25 \mathrm{a}$ & \multirow{2}{*}{10.53} & \multirow{2}{*}{11.61} \\
\hline & Leaves & $0.84 \mathrm{a}$ & $1.04 \mathrm{a}$ & $0.95 \mathrm{a}$ & $0.94 \mathrm{a}$ & $1.00 \mathrm{a}$ & $1.02 \mathrm{~b}$ & & \\
\hline \multirow{2}{*}{ FRM (g/plant) } & Soil & $9.89 \mathrm{~b}$ & $11.15 \mathrm{a}$ & $9.23 \mathrm{~b}$ & $10.35 \mathrm{a}$ & $10.33 \mathrm{a}$ & $13.91 \mathrm{a}$ & \multirow{2}{*}{15.59} & \multirow{2}{*}{11.81} \\
\hline & Leaves & $12.00 \mathrm{a}$ & $11.38 \mathrm{a}$ & $11.50 \mathrm{a}$ & $11.46 \mathrm{a}$ & $9.00 \mathrm{a}$ & $10.91 \mathrm{~b}$ & & \\
\hline \multirow{2}{*}{ DRM (g/plant) } & Soil & $1.62 \mathrm{a}$ & $1.62 \mathrm{a}$ & $1.13 \mathrm{a}$ & $1.59 \mathrm{a}$ & $1.85 \mathrm{a}$ & $2.53 \mathrm{a}$ & \multirow{2}{*}{18.71} & \multirow{2}{*}{22.52} \\
\hline & Leaves & $1.64 \mathrm{a}$ & $1.67 \mathrm{a}$ & $1.54 \mathrm{a}$ & $1.65 \mathrm{a}$ & $1.09 \mathrm{~b}$ & $1.25 \mathrm{~b}$ & & \\
\hline \multirow{2}{*}{ DHM (g/plant) } & Soil & $4.68 \mathrm{~b}$ & $5.72 \mathrm{a}$ & $6.01 \mathrm{a}$ & $5.96 \mathrm{a}$ & $6.28 \mathrm{a}$ & $6.85 \mathrm{a}$ & \multirow{2}{*}{4.06} & \multirow{2}{*}{7.57} \\
\hline & Leaves & $5.40 \mathrm{a}$ & $5.40 \mathrm{a}$ & $6.15 \mathrm{a}$ & $6.31 \mathrm{a}$ & $6.11 \mathrm{a}$ & $6.89 \mathrm{a}$ & & \\
\hline \multirow{2}{*}{ FHM (g/plant) } & Soil & $79.94 \mathrm{~b}$ & $97.04 \mathrm{a}$ & $100.28 \mathrm{~b}$ & $116.19 \mathrm{a}$ & $121.74 \mathrm{a}$ & $111.33 \mathrm{~b}$ & \multirow{2}{*}{14.36} & \multirow{2}{*}{8.39} \\
\hline & Leaves & $99.96 \mathrm{a}$ & $106.83 \mathrm{a}$ & $122.21 \mathrm{a}$ & $129.25 \mathrm{a}$ & $119.38 \mathrm{a}$ & $131.48 \mathrm{a}$ & & \\
\hline \multirow{2}{*}{ CY $\left(\mathrm{t} / \mathrm{ha}^{-1}\right)$} & Soil & $10.23 \mathrm{~b}$ & $12.42 \mathrm{a}$ & $12.83 \mathrm{~b}$ & $14.87 \mathrm{a}$ & $15.58 \mathrm{a}$ & $14.25 \mathrm{~b}$ & 1444 & \\
\hline & Leaves & $12.79 \mathrm{a}$ & $13.67 \mathrm{a}$ & $15.64 \mathrm{a}$ & $16.54 \mathrm{a}$ & $15.28 \mathrm{a}$ & $16.85 \mathrm{a}$ & 14.44 & 0. \\
\hline
\end{tabular}

*In the columns, the averages followed by the same letter, inside each characteristic, do not differ by the Tukey test at the level of $5 \%$ of probability; ${ }^{1}$ Plot; ${ }^{2}$ Subplot (*In columns, means followed by same letter within each trait, do not differ by the Tukey test at the level of $5 \%$ of probability; ${ }^{1}$ Plot; ${ }^{2}$ Split-plot).

the constant value of $0.96 \mathrm{~g} / \mathrm{plant}$. When applied on the soil, the DSM presented an increasing linear response to the concentrations applied, with an estimated increase of $0.33 \mathrm{~g} / \mathrm{plant}$, between the concentration of 0.0 and $1.25 \%$ (Figure 1E). A higher value was observed for the soil application only in the concentration of $1.25 \%$ (Table 1).

The SL is a characteristic related to the yield of the lettuce crop (Yuri et al., 2004), but it can also indicate the conditions that lead plants to flowering. Urine solutions promote the stem growth probably due to other factors besides nutrition. Possibly, there is a hormonal effect on the cell elongation, since the quantities of nutrients in these applications are much lower than those where chemical and/or organic fertilization is used for lettuce. Besides, the quantities of nutrients used in the applications are very small for the plant nutritional necessities.

The FRM did not present any response to the urine concentrations applied to leaves with constant value of $11.04 \mathrm{~g} /$ plant. In the soil application, a quadratic model response was obtained, with the maximum value of $13.29 \mathrm{~g} /$ plant (Figure 1F). Such application form presented the same behavior in the DRM, with the highest value of $2.51 \mathrm{~g} /$ plant also achieved in the highest concentration. On the other hand, the DRM presented a linear decrease for the concentrations applied to the leaves, varying from $1.73(0.0 \%)$ to $1.22 \mathrm{~g} /$ plant (1.25\%) (Figure 1G). The leaf application provided a higher FRM in the $0.50 \%$ concentration and a lower FRM in the concentration of $1.25 \%$, in relation to the soil application. In the concentrations of 1.00 and $1.25 \%$, the soil application provided higher DRM values in comparison to the leaf application (Table 1).

The increments of FRM and DRM in the higher urine concentrations applied in the soil can be explained by the stimulation in the production of photoassimilates for the expansion of the root system and demand of the aboveground part. In a research performed with lettuce in a greenhouse, Ricci (1993)verified that the traditional organic compound provided a higher 


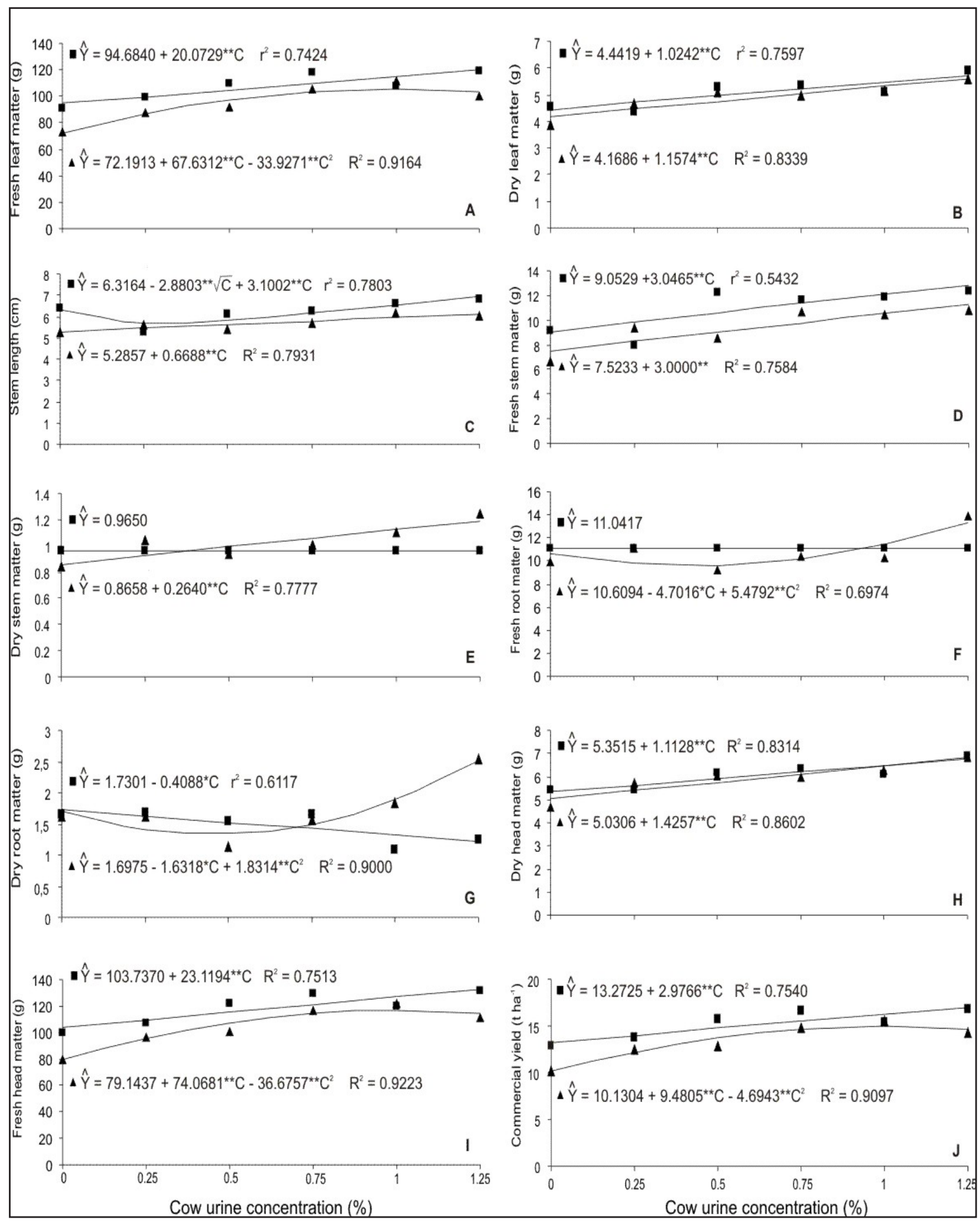

Figure 1. Estimate of foliar fresh and dry matter, stem length, stem fresh and dry matter, root fresh and dry matter, head fresh and dry matter, and commercial yield of lettuce, in function of application of cow urine concentrations via leaves ( $\mathbf{\square})$ and soil ( $(\mathbf{\Delta})$. ** and $*$ significant respectively at 1 and 5\% probability [estimativa de massa de matéria fresca e seca de folha, comprimento de caule, massa de matéria seca e fresca de caule, massa de matéria fresca e seca de raiz, massa de matéria seca e fresca de cabeça e produtividade comercial da alface, em função da aplicação de concentrações de urina de vaca vias folhas $(\boldsymbol{\square})$ e solo $(\boldsymbol{\Delta}){ }^{* *} \mathrm{e}^{*}$ significativos, respectivamente, a 1 e $5 \%$ de probabilidade]. Viçosa, UFV, 2006. 
root dry matter mass in relation to the vermicompost, which was attributed to the lower availability of nutrients of the traditional compound, since the higher root development occurred as a means for a better soil exploration.

The FHM and productivity presented linear responses to the concentrations applied on the leaves and a quadratic response for soil application (Figure 1IJ). With the leaf application, when increased from 0.0 to $1.25 \%$, the FHM varied from 103.73 to $132.63 \mathrm{~g} / \mathrm{plant}$ and the productivity, from 13.27 to $17.00 \mathrm{t} \mathrm{ha}^{-1}$. For soil application, the maximum FHM and productivity were achieved in the concentration of $1.01 \%$, with estimated values of $116.54 \mathrm{~g} /$ plant and $14.92 \mathrm{t} \mathrm{ha}^{-1}$. In the concentration of $1.25 \%$ applied on the leaves, the increase in productivity was $28.1 \%$, in comparison to the control. In the concentration of $1.01 \%$ (optimal concentration on the soil), the productivity increased to $47.3 \%$.

The DHM presented a linear increment for the urine concentrations applied on leaves and soil (Figure $1 \mathrm{H})$. The increases achieved from zero to $1.25 \%$, where 1.39 and 1.78 $\mathrm{g} / \mathrm{plant}$, corresponding to increases of $25.98 \%$ and $35.38 \%$, for leaf and soil applications, respectively. In the concentrations of 0.50 and $1.25 \%$, the plants which received urine applications on the leaves presented higher values of FHM and productivity, in comparison to the soil application (Table 1).

In the lettuce 'Vera', the maximum estimated of $348 \mathrm{~g}$ of fresh mass/plant was achieved with the dose of $23.0 \mathrm{t} \mathrm{ha}^{-1}$ of poultry litter applied as side dressing (Oliveira et al., 2006). In the lettuce 'Lucy Brown', the FHM increase was achieved with the application of coat manure and organic compound in doses of up to $160 \mathrm{t} \mathrm{ha}^{-1}$ (Cezar et al., 2003). As for cow urine, Gadelha (2003) achieved an FHM increase of $10.3 \%$, in lettuce 'Romana', comparing to the control, with the application of $20 \mathrm{ml}$ of urine solution per plant in the concentration of $0.86 \%$, achieving a productivity of $51.6 \mathrm{t} \mathrm{ha}^{-1}$.

In general, among the characteristics of the aboveground part evaluated, including yield, significantly higher values were achieved with the leaf application of cow urine, in comparison to the soil application. It demonstrates the efficiency of leaf absorption and the effectivity of the urine components. Among these components, there are macro and micronutrients, besides possible hormonal factors. Urea, one of the components present in urine, presents a faster absorption through the cuticle than the other compounds (Castellane et al., 1986).

This phenomenon, named "facilitated diffusion", occurs because urea breaks the chemical bonds between components of the cuticle (ester, ether, diester), which would then be transformed into a "net" with wider opening mesh. Besides, urea seems to increase the permeability of the cell membrane. Therefore, it also increases the absorption of ions $\mathrm{Fe}^{2+}$, $\mathrm{Zn}^{2+}, \mathrm{H}_{2} \mathrm{PO}_{4}^{-}$(Malavolta, 1997; Faquin, 1994). Besides urea, the elements K, $\mathrm{N}$ and $\mathrm{Cl}$ are present in significant concentrations in cow urine. In the form of ion $\mathrm{K}^{+}, \mathrm{NO}_{3}{ }^{-}$and $\mathrm{Cl}^{-}$, they may have promoted an increase in the cell turgor due to the osmotic effect (Faquin, 1994; Malavolta, 1997).

The plant growth resulting from the cow urine solution applied on the soil and, mainly, on the leaves, requires further understanding and elucidation. The increases in the production of mass of the head and lettuce yield with the increase in the urine concentrations, for both types of application, cannot be solely explained by the quantities of nutrients present in the urine solutions, since they were small, especially those of macronutrients, in comparison to the quantities of nutrients applied in chemical or organic fertilizations, which promote responses in lettuce plants.

Under the conditions of the present research, the results allowed to conclude that cow urine stimulates lettuce production, and the best results are achieved with the concentrations of $1.25 \%$ and $1.0 \%$ for leaf and soil applications, respectively.

\section{ACKNOWLEDGEMENTS}

To CAPES/PIQDTec/MEC for the master's scholarship granted to
Nelson Licínio Campos de Oliveira and FAPEMIG for the financial support and the scientific initiation scholarship granted to Pedro Henrique R Rodrigues (CAG APQ-0270-3.08/07 Project).

\section{REFERENCES}

ACHLIYA GS; MEGHRE VS; WADODKAR SG; DORLE AK. 2004. Antimicrobial activity of different fractions of cow urine. Indian Journal of Natural Products 20: 14-18.

ALVAREZ VH; RIBEIRO AC. 1999. Calagem. In: RIBEIROCA; GUIMARÃES PTG;ALVARES VH (eds). Comissão de Fertilidade do Solo do Estado de Minas Gerais - Recomendações para uso de corretivos e fertilizantes em Minas Gerais - $5^{a}$ Aproximação. Viçosa. p.43-60.

BOEMEKE LR. 2002. A urina de vaca como fertilizante, fortificante e repelente de insetos. Agroecologia e Desenvolvimento Rural Sustentável 3: 41-42.

CASTELLANE PD; SILVA EJ; MARTINS EF. 1986. A aplicação de uréia via foliar em alface 'Grand Rapids'. Horticultura Brasileira 4: 35 .

CÉZAR VRS; SOUZA TR; FERNANDES DM; VILLAS BOAS RL. 2003. Resposta da alface Americana a fontes e doses de material orgânico em condições de campo. In: CONGRESSO BRASILEIRO DE OLERICULTURA, 21. Resumos... Recife: SOB (CD-ROM).

CFSEMG-Comissão de fertilidade do solo do Estado de Minas Gerais. 1999. Adubação orgânica. In RIBEIRO AC; GUIMARÃES PT; ALVARES VH (eds). Comissão de Fertilidade do Solo do Estado de Minas Gerais - Recomendações para uso de corretivos e fertilizantes em Minas Gerais $5^{a}$ Aproximação. Viçosa. p. 90.

FAQUIN V. 1994. Nutrição Mineral de plantas. Lavras: ESAL-FAEPE. 227p.

FONTES PCR. 1999. Sugestões de adubação para de hortaliças. In: RIBEIRO AC; GUIMARÃES PT; ALVARES VH (eds). Comissão de Fertilidade do Solo do Estado de Minas Gerais - Recomendações para uso de corretivos e fertilizantes em Minas Gerais - $5^{a}$ Aproximação. Viçosa. p. 177.

GADELHA RSS; CELESTINO RCA; SHIMOYA A. 2002. Efeito da urina de vaca na produtividade do abacaxi. Pesquisa Agropecuária \& Desenvolvimento Sustentável 1: 91-95.

GADELHA RSS; CELESTINO RCA; SHIMOYA A. 2003. Efeito da utilização de urina de vaca na produção da alface. Pesquisa Agropecuária \& Desenvolvimento Sustentável 1: 179-182.

LOPES JC; RIBEIRO LG; ARAÚJO MG; BERALDO MRSBS. 2005. Produção de alface com doses de lodo de esgoto. Horticultura Brasileira 23: 143-147.

MALAVOLTA E. 1997. Avaliação do estado nutricional das plantas: princípios e aplicações. Piracicaba: Potafos. 319 p.

OLIVEIRA NG; DE-POLLI H; ALMEIDA DL; GUERRA JGM. 2006. Plantio direto 
de alface adubada com "cama" de aviário sobre coberturas vivas de grama e amendoim forrageiro. Horticultura Brasileira 24: 112117.

PESAGRO-RIO. 2002. Urina de vaca: alternativa eficiente e barata. (Documentos, n. 96). 8 p.

PÔRTO ML. 2006. Produção, estado nutricional e acúmulo de nitrato em plantas de alface submetidas à adubação nitrogenada e orgânica. Areia: UFPB. 65 p. (tese mestrado).

PRADO RM; COUTINHO ELM; ROQUE CG; VILLAR MLP. 2002. Avaliação da escória de siderurgia e de calcários como corretivos da acidez do solo no cultivo da alface. Pesquisa Agropecuária Brasileira 37: 539-546.

PRIMAVESI A. 1985. Manejo ecológico do solo: a agricultura em regiões tropicais. São Paulo: Nobel. 541 p.

RICCI MSF. 1993. Crescimento e teores em cultivares de alface (Lactuca sativa L.) adubados com vermicomposto. Viçosa: UFV. $101 \mathrm{p}$. (Tese doutorado).

SANTOS RHS; SILVA F; CASALI VWD; CONDÉAR. 2001. Efeito residual de adubação com composto orgânico sobre o crescimento e produção de alface. Pesquisa Agropecuária Brasileira 36: 1395-1398.

VIDIGAL SM; SEDIYAMA MAM; GARCIA NCP; MATOS AT. 1997. Produção de alface cultivada com diferentes compostos e dejetos de suínos. Horticultura Brasileira 15: 35-39.

VILAS BÔAS RL; PASSOS JC; FERNANDES
DM; BÜLL LT; CEZAR VRS; GOTO R. 2004. Efeitos de doses de compostos orgânicos na produção de alface em dois solos sob ambiente protegido. Horticultura Brasileira 22: $28-34$

YURI JE; RESENDE GM; RODRIGUES JÚNIOR JC; MOTA JH; SOUZA RJ. 2004. Efeito de composto orgânico sobre a produção e características comerciais de alface Americana. Horticultura Brasileira 22: 127-130.

ZÁRATE NAH; VIEIRA MC; CABEÇAS JÚNIOR O. 1997. Produção de alface em função de doses e formas de aplicação de cama de aviário semidecomposta. Horticultura Brasileira 15: 65-67. 